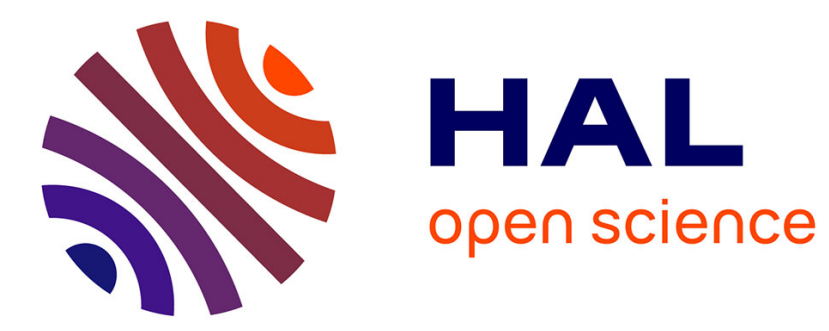

\title{
Programmable multimetallic linear nanoassemblies of ruthenium-DNA conjugates
}

\author{
Joris Irvoas, Arielle Noirot, Nadia Chouini-Lalanne, Olivier Reynes,
} Jean-Christophe Garrigues, Valérie Sartor

\section{To cite this version:}

Joris Irvoas, Arielle Noirot, Nadia Chouini-Lalanne, Olivier Reynes, Jean-Christophe Garrigues, et al.. Programmable multimetallic linear nanoassemblies of ruthenium-DNA conjugates. RSC Advances, 2012, vol. 2, pp. 9538-9542. 10.1039/c2ra21645k . hal-00925042

\section{HAL Id: hal-00925042 \\ https://hal.science/hal-00925042}

Submitted on 7 Jan 2014

HAL is a multi-disciplinary open access archive for the deposit and dissemination of scientific research documents, whether they are published or not. The documents may come from teaching and research institutions in France or abroad, or from public or private research centers.
L'archive ouverte pluridisciplinaire HAL, est destinée au dépôt et à la diffusion de documents scientifiques de niveau recherche, publiés ou non, émanant des établissements d'enseignement et de recherche français ou étrangers, des laboratoires publics ou privés. 


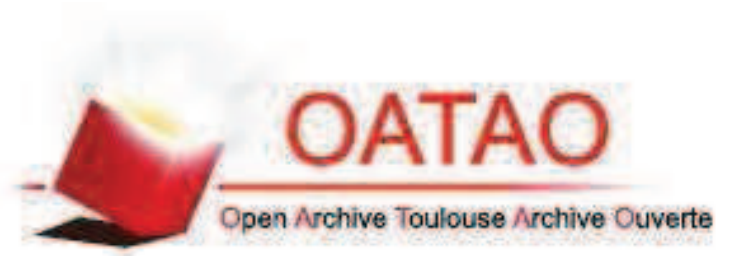

\section{Open Archive Toulouse Archive Ouverte (OATAO)}

OATAO is an open access repository that collects the work of Toulouse researchers and makes it freely available over the web where possible.

This is an author-deposited version published in: http://oatao.univ-toulouse.fr/ Eprints ID: 9990

To link to this article : DOI:10.1039/c2ra21645k

URL : http://dx.doi.org/10.1039/c2ra21645k

\section{To cite this version:}

Irvoas, Joris and Noirot, Arielle and Chouini-Lalanne, Nadia and Reynes, Olivier and Garrigues, Jean-Christophe and Sartor, Valerie Programmable multimetallic linear nanoassemblies of ruthenium-DNA conjugates. (2012) RSC Advances, vol. 2 (n 25). pp. 9538-9542. ISSN 2046-2069 


\title{
Programmable multimetallic linear nanoassemblies of ruthenium-DNA conjugates
}

\author{
Joris Irvoas, ${ }^{a b}$ Arielle Noirot, ${ }^{a b}$ Nadia Chouini-Lalanne, ${ }^{a b}$ Olivier Reynes, ${ }^{c d}$ Jean-Christophe Garrigues ${ }^{a b}$ and \\ Valerie Sartor*ab
}

\section{DOI: $10.1039 / \mathrm{c} 2 \mathrm{ra21645k}$}

A new ruthenium-DNA conjugates family was synthesized, made up of a ruthenium complex bound to one or two identical DNA strands of 14-58 nucleotides. The formation of controlled linear nanoassemblies containing one to seven ruthenium complexes is described.

\section{Introduction}

Metals are largely used by chemists to make original and varied nanostructures by complexation with organic backbones. ${ }^{1,2}$ More recently, inorganic complexes were employed to stabilize, to study and to form DNA assemblies. ${ }^{3-5}$ The nature of the metals used is as diverse as the nature of the assemblies formed. Ruthenium is one of them due to the remarkable photophysical and photochemical properties of ruthenium complexes, which can be easily modulated by the nature of the ligands employed. This allowed researchers to develop a wide range of applications concerning these components, for example, dye-sensitized solar cells, ${ }^{6}$ cancer treatments and medical diagnosis ${ }^{7,8}$ and catalysis. ${ }^{9}$ Despite the potential of these complexes in various fields of scientific research, only few examples of DNA assemblies involving ruthenium compounds are described. ${ }^{10-15}$

It was previously shown that the insertion of DNA backbones on terpyridine ruthenium complexes permitted the formation of linear arrays. ${ }^{11,12}$ The formation of cyclic structures has also been described. The control of the hybridization process allowed the formation of such constructions bearing one or two ruthenium molecules. ${ }^{13}$ Another original work reported the assembly of cyclic DNA architectures by using the tris $\left(2,2^{\prime}\right.$-bipyridine) ruthenium complex as a molecular template not being part of the structure, to control the duplex assembly. ${ }^{14}$ Furthermore, a star building block for future nanoassemblies was achieved. Indeed, a ruthenium tris(bipyridine) centre with

${ }^{a}$ Université de Toulouse; Université Paul Sabatier; Laboratoire IMRCP; Bat. II R1, 118 route de Narbonne, F-31062, Toulouse cedex 09, France. E-mail: sartor@chimie.ups-tlse.fr; Fax: +33 (0)5615581 55;

Tel: +33 (0) 56155256274

${ }^{b}$ CNRS; Laboratoire IMRCP UMR 5623, F-31062, Toulouse cedex 09 France.E-mail: sartor@chimie.ups-tlse.fr; Fax: +33 (0)5 615581 55; Tel: +33 (0)561556274

${ }^{c}$ Université de Toulouse; Université Paul Sabatier; Laboratoire de Genie Chimique; Bat. II R1, 118 route de Narbonne, F-31062, Toulouse cedex 09. France

${ }^{d}$ CNRS; LCG UMR 5503, F-31062, Toulouse cedex 09, France six identical oligonucleotide arms was synthesized and the formation of six DNA double strands surrounding the complex was shown. ${ }^{15}$

Considering the potential of ruthenium complexes on varied applications and the development of DNA hybridization strategies to construct nanodevices, we developed a very simple synthesis pathway to obtain ruthenium-DNA conjugates and a flexible hybridization strategy to control the distance and the position of the functionalized building blocks. The synthetic pathway is only based on two reaction steps and on commercially available modified oligonucleotides and chemical products. This synthetic strategy relies on the use of the carboxylic acid moiety. As it is a commonly used functionalization, it allows us to easily modulate the nature of the molecules inserted into DNA, therefore broadening the range of possible applications. In this paper, we describe the work made with $\mathrm{Ru}(\mathrm{II})\left(2,2^{\prime} \text {-bipyridine }\right)_{2}\left(4,4^{\prime}\right.$-dicarboxy2,2'-bipyridine) complex. ${ }^{16}$ We developed a new family of ruthenium complexes bearing one or two DNA single strands with lengths varying between 14 and 58 nucleic bases. The modular hybridization strategy is based on the choice of the oligonucleotide sequences. They have been wisely designed to self-assemble into linear nanoarrays in a modular fashion to lead to original onedimensional constructions with one to seven ruthenium complexes at different controlled positions and distances (Fig. 1).

\section{Results and discussion}

\section{Synthesis of ruthenium-DNA conjugates}

This new series of ruthenium-DNA hybrids were synthesized by coupling oligonucleotides substituted by an amino hexyl linker in the $5^{\prime}$ position with a $\mathrm{Ru}(\mathrm{II})\left(2,2^{\prime} \text {-bipyridine }\right)_{2}\left(4,4^{\prime}\right.$-dicarboxy$2,2^{\prime}$-bipyridine) complex. ${ }^{16}$ The amide link has been performed with the DNA strand kept on a solid support. The reaction took place using 4-(4,6-dimethoxy-1,3,5-triazin-2-yl)-4-methylmorpholinium chloride (DMT-MM) in $0.8 \mathrm{M}$ 3-morpholinopropane-1-sulfonic acid (MOPS) buffer $\left(\mathrm{pH}=7\right.$ ) in $\mathrm{DMSO} / \mathrm{H}_{2} \mathrm{O}$ solvents with a large excess of ruthenium complex. ${ }^{17}$ After deprotection and cleavage of crude DNA products from the solid 


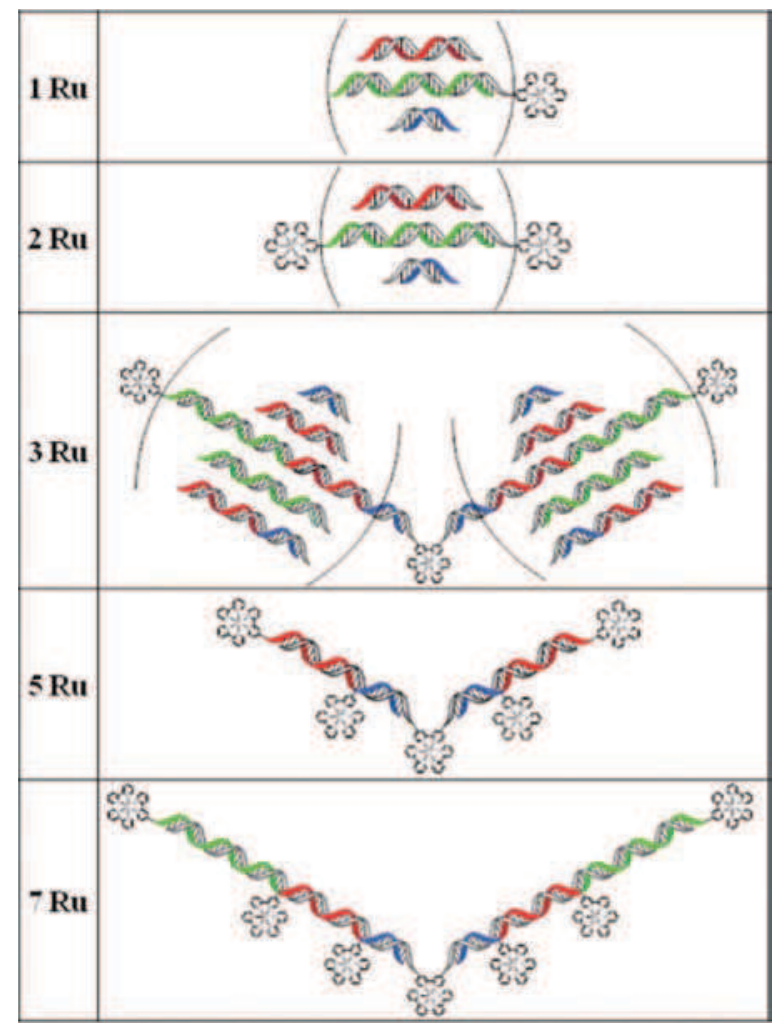

Fig. 1 Multimetallic linear nanoassemblies bearing one to seven ruthenium complexes and DNA sequence lengths of 14-58 nucleotides.

support, analysis and purification were realized using denaturing polyacrylamide gel electrophoresis (PAGE). The polyacrylamide gels were directly observed under UV light at two wavelengths (254 and $365 \mathrm{~nm}$ ), which were convenient to discriminate DNA and $\mathrm{Ru}-\mathrm{DNA}$ conjugates. Indeed, at $\lambda=365 \mathrm{~nm}$ or on a Safe Imager $^{\mathrm{TM}} 2.0$ Blue-light transilluminator, the presence of a $\mathrm{Ru}$ centre induces a characteristic orange luminescence. The latter does not appear at $\lambda=254 \mathrm{~nm}$, but DNA is still visible. Two molecules per reaction were isolated and characterized both carrying a ruthenium complex. The fast-moving orange band in the gel corresponds to the incorporation of one DNA sequence on the ruthenium complex. The slowest moving orange band in the gel was identified as the bis-DNA-functionalized ruthenium complex centre. With this experimental protocol, we obtained a family of ruthenium-DNA hybrids constituted of one $14(\mathbf{1 m}$ and $\mathbf{2 m}$ ), two $14(\mathbf{2 b})$, one $20(\mathbf{3 m}$ and $\mathbf{4 m})$, two $20(\mathbf{4 b})$, one 24 $(\mathbf{5 m}$ and $\mathbf{6 m})$, two $24(\mathbf{6 b})$, two $34(\mathbf{7 b})$ or two $58(\mathbf{8 b})$ nucleotide arms (Fig. 2).

The modified oligonucleotides were characterized by PAGE, UV-Vis and fluorescence spectrophotometries and mass spectroscopy.

The polyacrylamide gel electrophoresis of this new family of ruthenium-DNA conjugates was visualized directly on a Safe Imager $^{\mathrm{TM}} 2.0$ Blue-light transilluminator (Fig. 3). The increase of the sequence lengths and the insertion of two DNA single strands on one ruthenium complex consequently showed a decreased migration length of the molecules in the gel.

The UV-Vis absorption spectra of these conjugates show at $\lambda$ $=260 \mathrm{~nm}$ the characteristic band of DNA oligomers and at $\lambda=$

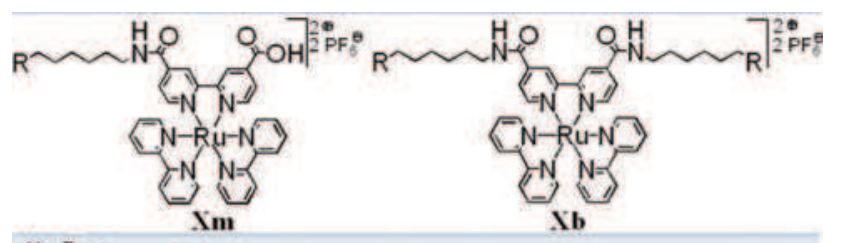

$\mathrm{X} R=$

1 5'-AGG TCT TCA GTA CG -3'

2 5'-CGT ACT GAA GAC CT -3'

3 5'- GAG ACT CGA CGC TGC ATG AG -3'

4 5'- CTC ATG CAG CGT CGA GTC TC - 3'

5 5'- CGG ACT CAG AGG CAG GCT TGC TAC - 3'

6 5'- GTA GCA AGC CTG CCT CTG AGT CCG -3'

7 5'- CGT ACT GAA GAC CTC TCA TGC AGC GTC GAG TCT C - 3'

5'-CGT ACT GAA GAC CTC TCA TGC AGC GTC GAG TCT CGT AGC

8 AAG CCT GCC TCT GAG TCC G -3'

Fig. 2 Synthesized mono-DNA-functionalized ruthenium complexes $(\boldsymbol{X} \mathbf{m})$ and bis-DNA-functionalized ruthenium complexes $(\boldsymbol{X} \mathbf{b})$ with their corresponding sequences.

$280 \mathrm{~nm}$ and $\lambda=458 \mathrm{~nm}$, the bipyridine $\pi-\pi^{*}$ and the complex MLCT (metal-to-ligand charge-transfer) transitions, respectively. The fluorescence spectra are all identical and characteristic of the ruthenium complex, namely having an emission peak at $\lambda=650 \mathrm{~nm}$ with an excitation wavelength at $458 \mathrm{~nm}$. An example of UV-Vis and fluorescence spectra of a mono DNAfunctionalized ruthenium complex is shown in Fig. 4.

High resolution electrospray mass spectra of $\mathbf{1 m}, \mathbf{2 m}, \mathbf{2 b}, \mathbf{3 m}$, $\mathbf{4 m}, \mathbf{4 b}$ and $\mathbf{5 m}$ confirm the structure of these ruthenium-DNA conjugates (see in ESI $\dagger$ ). The compounds $\mathbf{6 m}, \mathbf{6 b}, \mathbf{7 b}$ and $\mathbf{8 b}$ did not provide HRMS. However, the migration of their bands in PAGE compared to the fully characterized compounds and the presence of a ruthenium signal in UV-Vis and fluorescence spectrophotometries provided convincing evidence and characterizations of theirs structures.

\section{Multimetallic linear nanoassemblies}

The selective and specific hybridization of these rutheniumDNA conjugates afforded a variety of linear assemblies. They provided DNA double helices with a length of 14 to twice 58

\section{$\begin{array}{llllllllllll}1 & 2 & 3 & 4 & 5 & 6 & 7 & 8 & 9 & 10 & 11\end{array}$}

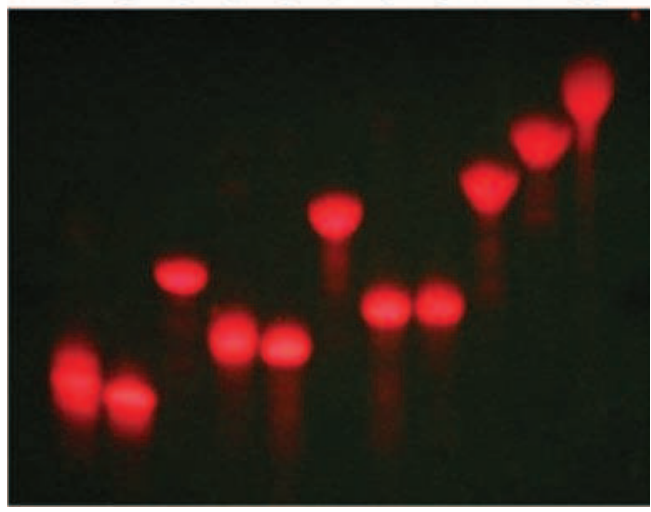

Fig. 3 Denaturing PAGE analysis of ruthenium-DNA conjugates on a Safe Imager $^{\mathrm{TM}} 2.0$ Blue-light transilluminator. Lane 1: 1m; lane 2: $\mathbf{2 m}$; lane 3: $\mathbf{2 b}$; lane 4: $\mathbf{3 m}$; lane 5: $\mathbf{4 m}$; lane 6: $\mathbf{4 b}$; lane 7: $\mathbf{5 m}$; lane 8: $\mathbf{6 m}$; lane 9: 6b; lane 10: $7 \mathbf{b}$; lane 11: $8 \mathbf{b}$. 


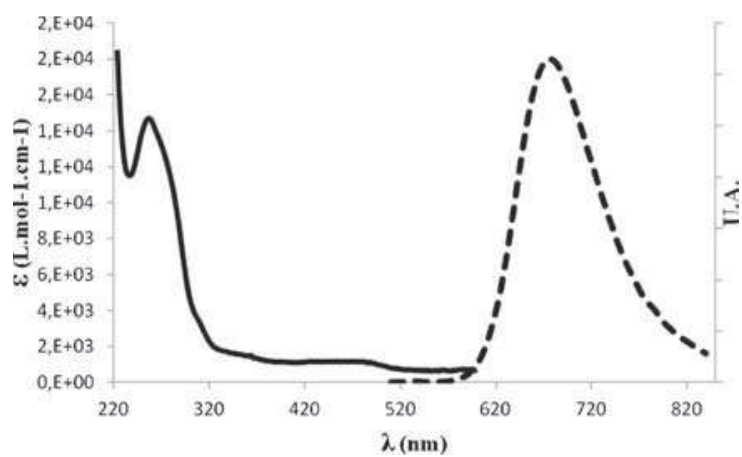

Fig. 4 UV-Vis (solid line) and fluorescence emission (dash line) spectra of $\mathbf{1 b}$.

base pairs and made up of one to seven ruthenium polypyridine complexes (Fig. 1). They were highlighted by native PAGE (Fig. 5 and 6 and in ESI†).

Hybridization of mono DNA-functionalized ruthenium complex $\mathbf{1 m}$ with $\mathbf{2}$ or $\mathbf{2 m}$ yields a 14-base double strand with one (Fig. 5, lane 3) or two ruthenium moieties (Fig. 5, lane 4), respectively. Similar assemblies were obtained based on the mono 20 (Fig. 5, lanes 6 and 7) and 24 (Fig. 5, lanes 9 and 10) nucleotide-long DNA-substituted ruthenium conjugates. Three ruthenium complex-DNA duplex structures were built by hybridization of the bis(DNA)-ruthenium hybrids with two equivalents of the sequence complementary mono(DNA)-ruthenium conjugates (Fig. 6). In these three-ruthenium assemblies,

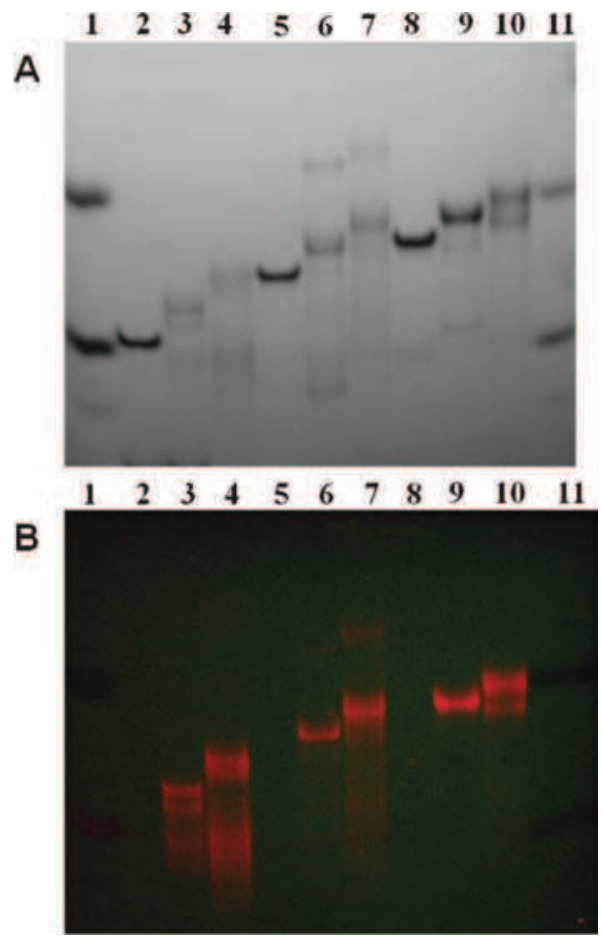

Fig. 5 Non-denaturing PAGE analysis of linear assemblies with 0,1 and 2 ruthenium complexes with $\lambda=254 \mathrm{~nm}$ (A) and on Safe Imager ${ }^{\mathrm{TM}}$ (B). Lanes 1 and 11: two products for migration control, upper: xylene cyanol, lower: bromophenol blue; lane $2: \mathbf{1}+\mathbf{2}$; lane $3: \mathbf{1 m}+\mathbf{2}$; lane $4: \mathbf{1 m}$ + 2m; lane $5: \mathbf{3}+\mathbf{4}$; lane $6: \mathbf{3 m}+\mathbf{4}$; lane $7: \mathbf{3 m}+\mathbf{4 m}$; lane $8: \mathbf{5}+\mathbf{6}$; lane $9:$ $5 \mathbf{m}+\mathbf{6}$; lane 10: $\mathbf{5 m}+\mathbf{6 m}$.

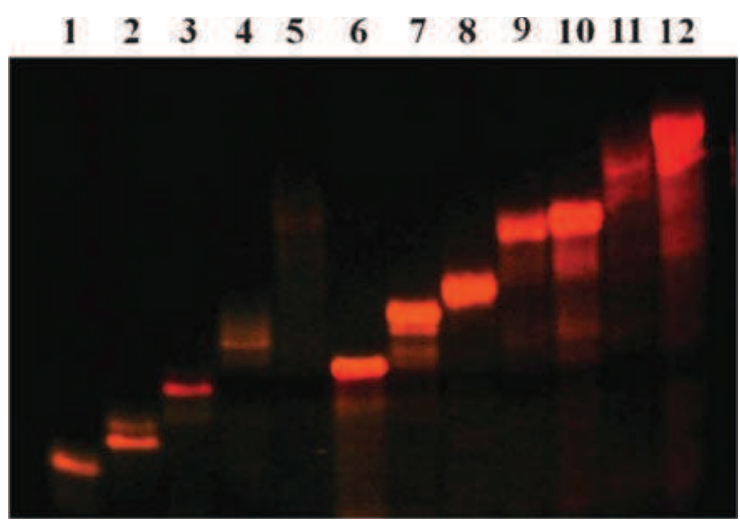

Fig. 6 Non-denaturing PAGE analysis of multimetallic linear assemblies on Safe Imager ${ }^{\mathrm{TM}}$. Lane 1: $\mathbf{2 b}$; lane 2: $\mathbf{4 b}$; lane 3: $\mathbf{6 b}$; lane 4: 7b; lane 5: $\mathbf{8 b}$; lane 6: $\mathbf{2 b}+2 \times \mathbf{1 m}$; lane 7: $\mathbf{4 b}+2 \times \mathbf{3 m}$; lane $8: \mathbf{6 b}+2 \times \mathbf{5 m}$; lane 9: $\mathbf{7 b}+2 \times \mathbf{1}+2 \times \mathbf{3 m}$; lane 10: $\mathbf{7 b}+2 \times \mathbf{1 m}+2 \times \mathbf{3 m}$; lane 11: $\mathbf{8 b}+2$ $\times \mathbf{1}+2 \times \mathbf{3}+2 \times \mathbf{5 m}$; lane $12: \mathbf{8 b}+2 \times \mathbf{1 m}+2 \times \mathbf{3 m}+2 \times \mathbf{5 m}$.

the distances between two ruthenium complexes are modulated by the duplexes lengths, which are 14 (lane 6), 20 (lane 7), 24 (lane 8), 34 (lane 9) or 58 (lane 11) base pairs long.

To easily and efficiently modulate the number of ruthenium motifs and their positions in the linear assemblies, the 34 and 58 nucleotide-long DNA oligomers 7 and $\mathbf{8}$ were designed to be successively composed with the 14- and 20-base sequences ( 1 and 2) and 14-, 20- and 24-base sequences (1, 2 and 3), respectively. Consequently, longer three-ruthenium linear assemblies were generated by hybridization of the bis(34 bases oligonucleotide)ruthenium hybrid $\mathbf{7 b}$ with two complementary mono(20 bases oligonucleotide) $-\mathrm{Ru}$ conjugates $\mathbf{3 m}$ and two 14 nucleotide-long single strands 1 (Fig. 6 lane 9). Hybridization of the bis(58 bases oligonucleotide)-ruthenium hybrid $\mathbf{8 b}$ with two complementary mono(24 bases oligonucleotide)-Ru conjugates $\mathbf{5 m}$ and two 14 and 20 nucleotide-long single strands $\mathbf{1}$ and $\mathbf{3}$ led to an even longer three-ruthenium linear structure (Fig. 6 lane 11). This approach allowed us to easily adjust and increase the number of ruthenium moieties in the architecture. Indeed, it was achieved by using Ru-DNA conjugates instead of DNA single strands in the previously formed structures. With this methodology, hybridization of $\mathbf{7 b}$ with 2 eq. of $\mathbf{1 m}$ and $\mathbf{3 m}$ (Fig. 6, lane 10), and $\mathbf{8 b}$ with 2 eq. of $\mathbf{1 m}, \mathbf{3 m}$ and $\mathbf{5 m}$ (Fig. 6, lane 12) provided linear DNA assemblies bearing five and seven ruthenium complexes, respectively.

All of these linear assemblies were studied by UV-thermal denaturation experiments and circular dichroism (CD) spectroscopy.

The melting temperature $\left(T_{\mathrm{m}}\right)$ analysis shows no significant difference in $T_{\mathrm{m}}$ values for duplexes in presence of no, one, two or three ruthenium complexes (Table 1). Nevertheless, the $T_{\mathrm{m}}$ curves are broadened ( $T_{\mathrm{m}}$ curves available in ESI $\dagger$ ). The metallic motifs seem to affect the thermal stability of the double helices. It can be watched on the polyacrylamide gel in Fig. 5. The bands for one- and two-ruthenium-DNA conjugate duplexes (lanes 3, 4, 6, 7, 9 and 10) are thicker and more diffuse than duplexes without a ruthenium complex (lanes 2, 5 and 8). For the 34 and 58 base pair duplexes formed with two and three distinct double strands, respectively, two $T_{\mathrm{m}}$ were observed, the values 
Table 1 Melting temperatures of linear assemblies

\begin{tabular}{lll}
\hline Linear assemblies & $T_{\mathrm{m}} 1\left({ }^{\circ} \mathrm{C}\right)$ & $T_{\mathrm{m}} 2\left({ }^{\circ} \mathrm{C}\right)$ \\
\hline $\mathbf{1}+\mathbf{2}$ & 47.3 & \\
$\mathbf{1} \mathbf{m}+\mathbf{2}$ & 48 & \\
$\mathbf{1} \mathbf{m}+\mathbf{2} \mathbf{m}$ & 48 & \\
$\mathbf{3}+\mathbf{4}$ & 68 & \\
$\mathbf{3} \mathbf{m}+\mathbf{4}$ & 67.5 & \\
$\mathbf{3} \mathbf{m}+\mathbf{4} \mathbf{5}$ & 68.5 & \\
$\mathbf{5}+\mathbf{6}$ & 71.1 & \\
$\mathbf{5} \mathbf{m}+\mathbf{6}$ & 72.2 & \\
$\mathbf{5} \mathbf{m}+\mathbf{6} \mathbf{m}$ & 71.2 & \\
$\mathbf{2 b}+2 \times \mathbf{1} \mathbf{m}$ & 51 & 66.6 \\
$\mathbf{4 b}+2 \times \mathbf{3} \mathbf{5}$ & 67.8 & 66.8 \\
$\mathbf{6 b}+2 \times \mathbf{5 m}$ & 72.2 & 70.1 \\
$\mathbf{7 b}+2 \times \mathbf{1}+2 \times \mathbf{3 m}$ & 54 & 69 \\
$\mathbf{7 b}+2 \times \mathbf{1} \mathbf{m}+2 \times \mathbf{3 m}$ & 54 & \\
$\mathbf{8 b}+2 \times \mathbf{1}+2 \times \mathbf{3}+2 \times \mathbf{5 m}$ & 58.3 & \\
$\mathbf{8 b}+2 \times \mathbf{1} \mathbf{m}+2 \times \mathbf{3 m}+2 \times \mathbf{5 m}$ & - & \\
\hline
\end{tabular}

corresponding to an average of the hybridization temperatures of the separate double strands.

Circular dichroism (CD) was used to check Ru complex effects on the duplex integrity. The $\mathrm{CD}$ spectra are identical for the whole duplex family. They present a characteristic spectrum of DNA B form with a positive band at $282 \mathrm{~nm}$ and a negative band at $252 \mathrm{~nm}$ (Fig. 7). No CD signal next to the MLCT band of the ruthenium complex was observed. The presence of internal and/ or terminal metallic centres did not affect the CD signals and thus the shape of the duplexes.

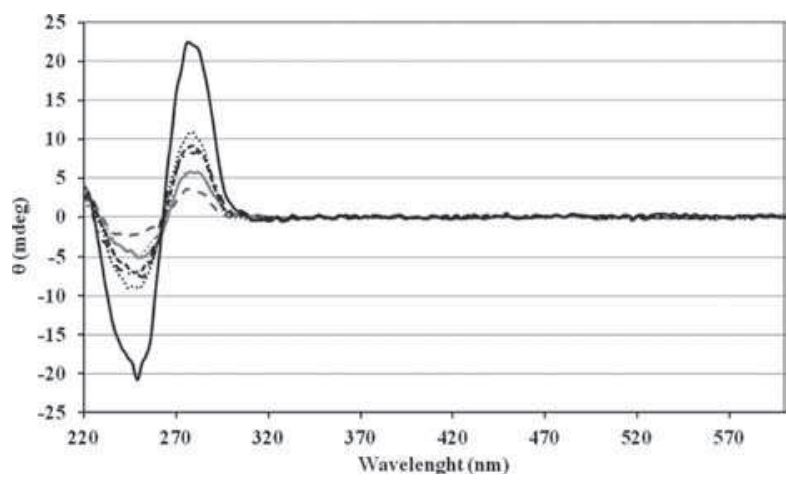

Fig. 7 Circular dichroism spectra of $\mathbf{2 b}+2 \times \mathbf{1 m}$ (dash grey line); $\mathbf{4 b}+$ $2 \times \mathbf{3 m}$ (grey line); $\mathbf{6 b}+2 \times \mathbf{5 m}$ (dash dot black line); $\mathbf{7 b}+2 \times \mathbf{1}+2 \times$ $\mathbf{3 m}$ (dot grey line); $\mathbf{7 b}+2 \times \mathbf{1} \mathbf{m}+2 \times \mathbf{3 m}$ (dash black line); $\mathbf{8 b}+2 \times \mathbf{1}+$ $2 \times \mathbf{3}+2 \times \mathbf{5 m}$ (black line) $; \mathbf{8 b}+2 \times \mathbf{1 m}+2 \times \mathbf{3} \mathbf{m}+2 \times \mathbf{5 m}$ (dot black line).

\section{Conclusions}

Herein, we have shown the synthesis and the characterization of a new family composed of eleven mono- and bis-DNAfunctionalized ruthenium complexes. A simple and efficient route was described to assemble ruthenium complexes in a linear and programmable fashion using the DNA self-assembly property. This strategy allowed us to selectively choose the number and the position of metallic complexes introduced in a DNA backbone. The extension of this methodology could afford symmetrical nanowires of various lengths with other metals.

\section{Experimental}

\section{Materials and methods}

5'-C6 amino-modified oligonucleotides were purchased from Eurogentech. 4,4'-dicarboxy-2,2'-bipyridine, cis-bis(2,2'-bipyridine) dichlororuthenium(II) and 3-morpholinopropane-1-sulfonic acid (MOPS) was purchased at Alfa-Aesar France. 4-(4,6-dimethoxy1,3,5-triazin-2-yl)-4-methylmorpholinium chloride (DMT-MM) was purchased at Sigma Aldrich France. $\left[\mathrm{Ru}^{2+}\left(2,2^{\prime} \text {-bipyridine }\right)_{2}\right.$ $\left(4,4^{\prime}\right.$-dicarboxy-2,2'-bipyridine $]\left(\mathrm{PF}_{6}{ }^{-}\right)_{2}$ was synthesized as already reported. ${ }^{16}$

UV-Vis spectra were obtained using Hewlett-Packard 8452A equipment. Fluorescence spectra were acquired on a Photon Technology International modular setup. Circular dichroism was achieved on a Jasco J-815 CD spectrometer. Polyacrylamide gel electrophoresis (PAGE) analysis was carried out on a Hoefer SE40-15-1.5 unit and the gels finally visualized on a Safe Imager $^{\mathrm{TM}} 2.0$ blue light transilluminator, under UV light at $\lambda=$ $254 \mathrm{~nm}$ or at $\lambda=365 \mathrm{~nm}$. HRMS analyses were realized on a Qtof Ultima API (Waters) mass spectrometer, see ESI $\dagger$. The capillary, cone and RF Lens tensions were, respectively, $3.5 \mathrm{kV}$, $130 \mathrm{~V}$ and $40 \mathrm{~V}$. The source and desolvation temperatures were $60{ }^{\circ} \mathrm{C}$ and $80{ }^{\circ} \mathrm{C}$. The collision energy (Ar) was fixed at $8 \mathrm{eV}$ in Tof ms mode, with nitrogen for the nebulization gas. The solutions were analyzed by infusion $\left(10 \mu \mathrm{L} \min ^{-1}\right)$, with an acquisition time of $5 \mathrm{~min}$, realized with the Masslynx 4.1 software (Waters).

\section{General procedure for ruthenium-DNA hybrids synthesis}

A $2 \mathrm{~mL}$ aqueous buffer solution $(\mathrm{pH}=7)$ of 3-morpholinopropane-1-sulfonic acid (MOPS) (1,046 g, $\left.0.8 \mathrm{~mol} \mathrm{~L}^{-1}\right)$ and 4(4,6-dimethoxy-1,3,5-triazin-2-yl)-4-methylmorpholinium chloride (DMT-MM) $\left(138,4 \mathrm{mg}, 0.08 \mathrm{~mol} \mathrm{~L}^{-1}\right)$ was prepared. $4 \mathrm{~mL}$ DMSO solution of $\left[\mathrm{Ru}^{2+}\left(2,2^{\prime} \text {-bipyridine }\right)_{2}\left(4,4^{\prime}\right.\right.$-dicarboxy-2, $2^{\prime}$-bipyridine $\left.)\left(\mathrm{PF}_{6}{ }^{-}\right)_{2}\right)(4,7 \mathrm{mg}, 5 \mu \mathrm{mol}, 25$ eq. $)$ was added, followed by the introduction of 5'-C6 amino-modified oligonucleotide kept on a solid support (200 nmol, 1 eq.). The solution was stirred for $48 \mathrm{~h}$ at $25{ }^{\circ} \mathrm{C}$ and then filtered. The resulting orange beads were washed once with DMSO and 3 times with water. The beads were put in a concentrated ammonia solution $(32 \%)$ at $55{ }^{\circ} \mathrm{C}$ for $20 \mathrm{~h}$ and then filtered. The filtrate was evaporated and redissolved in an aqueous solution. Ruthenium-DNA conjugates were purified by PAGE on $20 \%$ denaturing polyacrylamide gels. The bands were cut, crushed in water and incubated at $55{ }^{\circ} \mathrm{C}$. The mixture was filtered to remove the gel. The filtrate was concentrated and washed twice with water on a Amicon $\mathbb{R}$ Ultra centrifugal filter $3 \mathrm{~K}$ (Millipore Ireland Ltd).

\section{Hybridization conditions}

A solution with the appropriated number of equivalents of each DNA strand was prepared for a final $50 \mu \mathrm{M}$ (duplex) concentration in a buffer solution $(50 \mathrm{mM}$ Tris, $100 \mathrm{mM} \mathrm{NaCl}$ and $10 \mathrm{mM} \mathrm{MgCl}$ at $\mathrm{pH}=7.2$ ). Hybridization was achieved by heating this solution to $90{ }^{\circ} \mathrm{C}$ for $3 \mathrm{~min}$ and then leaving its temperature to decrease slowly to room temperature. The solution was finally incubated for $12 \mathrm{~h}$ at $4{ }^{\circ} \mathrm{C}$. 


\section{Acknowledgements}

Financial support was provided by the French National Agency of Research (ANR) (ANR-08-JCJC-0141).

\section{References}

1 Y. E. Alexeev, B. I. Kharisov, T. C. H. Garcia and A. D. Garnovskii, Coord. Chem. Rev., 2010, 254, 794-831.

2 R. Chakrabarty, P. S. Mukherjee and P. J. Stang, Chem. Rev., 2011, 111, 6810-6918.

3 H. Yang, K. L. Metera and H. F. Sleiman, Coord. Chem. Rev., 2010, 254, 2403-2415.

4 S. Ghosh and E. Defrancq, Chem.-Eur. J., 2010, 16, 12780-12787.

5 J. Müller, Eur. J. Inorg. Chem., 2008, 2008, 3749-3763.

6 G. C. Vougioukalakis, A. I. Philippopoulos, T. Stergiopoulos and P. Falaras, Coord. Chem. Rev., 2011, 255, 2602-2621.

7 O. Lentzen, C. Moucheron and A. K.-D. Mesmaekerin Metallotherapeutic Drugs and Metal-Based Diagnostic Agents, John Wiley \& Sons, Ltd, 2005, pp. 359-378.
8 W. H. Ang, A. Casini, G. Sava and P. J. Dyson, J. Organomet. Chem., 2011, 696, 989-998.

9 A. L. Noffke, A. Habtemariam, A. M. Pizarro and P. J. Sadler, Chem. Commun., 2012, 48, 5219-5246.

10 K. Wiederholt and L. W. McLaughlin, Nucleic Acids Res., 1999, 27, 2487-2493.

11 K. M. Stewart and L. W. McLaughlin, Chem. Commun., 2003, 2934-2935.

12 S. Ghosh, I. Pignot-Paintrand, P. Dumy and E. Defrancq, Org. Biomol. Chem., 2009, 7, 2729-2737.

13 D. Mitra, N. Di Cesare and H. F. Sleiman, Angew. Chem., Int. Ed., 2004, 43, 5804-5808.

14 F. A. Aldaye and H. F. Sleiman, J. Am. Chem. Soc., 2007, 129, 10070-10071.

15 K. M. Stewart, J. Rojo and L. W. McLaughlin, Angew. Chem., Int. Ed., 2004, 43, 5808-5811.

16 E. Terpetschnig, H. Szmacinski, H. Malak and J. R. Lakowicz, Biophys. J., 1995, 68, 342-350.

17 X. Li, J. Gartner, B. N. Tse and D. R. Liu, J. Am. Chem. Soc., 2004, 126, 5090-5092. 